\title{
EVALUASI PROSES BELAJAR MAHASISWA DALAM AKUNTANSI BIAYA DENGAN STRATEGI PENINJAUAN KEMBALI "HOLLY-WOOD SQUARES"
}

\author{
Marwanto 1), Lewi Patabang 2) \\ Politeknik Negeri Samarinda \\ Program Studi Akuntansi Manajerial \\ Jalan Cipto Mangunkusumo, Samarinda Seberang \\ 1) marwantopolnes@ gmail.com \\ ${ }^{2)}$ lewipatabang@gmail.com
}

\begin{abstract}
Abstrak
Penelitian dilakukan oleh Marwanto dan Lewi Patabang bertujuan untuk menguji penerapan strategi peninjauan kembali "Hollywood Square" dalam pemahaman dasar pengelompokkan biaya dan sistem akuntansi biaya di mata kuliah akuntansi biaya yang diajarkan di semester gasal 2016/2017. Data yang diperoleh dari partisipasi mahasiswa semester III Jurusan Akuntansi Politeknik Negeri Samarinda. Hasil penelitian menunjukkan prestasi belajar mahasiswa mengalami peningkatan di setiap siklusnya. Hasil tes sebelum Strategi Peninjauan Kembali model Permainan "Holly-wood Squares" diterapkan, yang memperoleh nilai minimal 71 sebanyak $0 \%$, setelah penerapan strategi ini yang memperoleh nilai minimal 71 sebanyak 75,53\%. Hasil pengamatan mengenai ketrampilan dosen dalam pengelolaan pembelajaran dengan Strategi Peninjauan Kembali model Permainan "Holly-wood Squares" dengan rentangan 1 - 4 menunjukkan hasil baik dengan rata-rata siklus 1 dan siklus 2 sebesar 3,5. Sedangkan minat, keaktifan dan kerjasama mahasiswa dalam proses pembelajaran dengan rentangan $1-4$ hasilnya baik $(3,58)$. Skor tersebut merupakan rata-rata dari seluruh aspek yang diamati pada dua siklus.
\end{abstract}

Kata kunci: evaluasi, pemahaman, Hollywood square.

\begin{abstract}
The research conducted by Marwanto and Patabang, Lewi was aimed to examine the judicial review strategy "Hollywood Square" application in the process of both the cost classification and cost accounting system in odd semester $2016 / 2017$. Data obtained was from the participation of the semester III students of Accounting Department Samarinda State Polytechnic. The result showed that the students' learning performance increased in every cycle. The pre-test results was $0 \%$ of minimum score 71 but pst-test result was $75.53 \%$. The observation result about the lecturer skill in managing the learning with the Judicial Review Strategy "Hollywood Square" with range 1-4 showed Good Score with the average cycle I and cycle II as much as 3.5. Moreover, the student interest, the activity as well as the teamwork in the learning process with range 1-4 was Good (3.58). The score was the average of all observed aspects in these two cycle.
\end{abstract}

The word keys: evaluation, comprehension, Hollywood Square

\section{Pendahuluan}

Peraturan Presiden Nomor 08 tahun 2012 [7], tentang Kerangka Kualifikasi Nasional Indonesia (KKNI), merupakan acuan yang bersifat legal formal dalam penataan kualifikasi nasional dalam bidang ketenagakerjaan. Perpres ini juga menjadi rujukan bagi dunia pendidikan dan lembaga pelatihan dalam merumuskan kurikulum dan program pelatihan, bagi lembaga sertifikasi profesi dalam melaksanaan sertifikasi kompetensi (uji kompetensi) dan merumuskan lingkup (skema sertifikasi), dan bagi dunia industri dalam proses rekruitment terutama terkait dengan pengakuan tingkat kualifikasi tenaga kerja yang dibutuhkan. Hal Ini dapat dicapai melalui pendidikan, pelatihan, dan pengalaman dalam rangka meningkatkan kompetensi para teknisi akuntansi yang mencakup knowledge (pengetahuan), skills (ketrampilan), dan attitude (sikap kerja).

Kemampuan kerja yang memenuhi ketiga aspek tersebut dinyatakan sebagai kompetensi, oleh karenanya disebut standar kompetensi kerja. Undang-Undang Nomor 13 Tahun 2003 [10] tentang Ketenagakerjaan juga mengatur bahwa pelatihan kerja diselenggarakan berdasarkan 
program 3 pelatihan yang mengacu pada standar kompetensi kerja (Pasal 10), yaitu ranah pengetahuan (kognitif), ranah ketrampilan (psikomotor), dan ranah sikap (afektif). Salah satunya dalam Akuntansi Biaya, mata kuliah yang disampaikan kepada mahasiswa setelah menempuh mata kuliah Pengantar Akuntansi 1, dan Pengantar Akuntansi 2. Mata kuliah Akuntansi Biaya diajarkan di Jurusan Akuntansi Program Studi D3 Akuntansi Semester III dan Program Studi D4 Akuntansi Manajerial Semester III sebagai salah satu mata kuliah keahlian. Proses belajar mengajar yang selama ini dilaksanakan oleh pengajar (dosen) adalah dengan penyampaian materi melalui metode ceramah dan pemberian tugas terstruktur yang menunjang pemahaman kognitif mahasiswa. Upaya meningkatkan pemahaman terhadap materi biaya yang kontekstual, dengan teori, konsep, dan aspek teknis dapat dilakukan melalui strategi peninjauan kembali. Strategi peninjauan kembali selain menjadi aktif, dapat menjadikan peninjauan kembali sebagai aktivitas yang menyenangkan (Melvin L. Silberman, 2006) [9]. Salah satu strategi peninjauan kembali yang dikembangkan oleh Melvin L. Silberman [9] adalah permainan "Holly-wood Squares".

Proses belajar mengajar yang selama ini dilaksanakan oleh pengajar (dosen) adalah dengan penyampaian materi melalui metode ceramah dan pemberian tugas terstruktur yang menunjang pemahaman kognitif mahasiswa. Karakteristik pendidikan di perguruan tinggi dengan pelajaran yang berlangsung cepat, pemahaman harus lebih mendalam, cara pengajaran dosen, pengaturan pelajaran, kegiatan belajar, hubungan dengan dosen, pengawasan terhadap mahasiswa, kultur dan norma baru (LP3-ITB, 2003) [5] menuntut mahasiswa untuk aktif dan kreatif terutama dalam pengembangan pemahamannya. Proses belajar mengajar yang telah dilakukan mengakibatkan mahasiswa cenderung menghafalkan materi sebagai cara yang mudah untuk memahami. Pemahaman atas keterkaitan logis antar konsep, teori, aspek teknik kurang ditekankan secara efektif sehingga mahasiswa cenderung menghafal, kurang kreatif, dan sulit mengembangkan kemampuan kognitifnya.

Metode pembelajaran yang mampu meningkatkan kemampuan belajar mahasiswa sangat diperlukan. Upaya meningkatkan pemahaman terhadap materi biaya yang kontekstual, dengan teori, konsep, dan aspek teknis dapat dilakukan melalui strategi peninjauan kembali. Salah satu cara untuk membuat pembelajaran tetap melekat dalam pikiran adalah dengan mengalokasikan waktu untuk meninjau kembali apa yang telah dipelajari. Materi yang telah dibahas oleh mahasiswa cenderung lima kali lebih melekat di dalam pikirannya. Itu karena pembahasan kembali memungkinkan mahasiswa untuk memikirkan kembali informasi tersebut dan menemukan cara untuk menyimpannya di dalam otak.

Kondisi tersebut dapat dirumuskan ke dalam pertanyaan penelitian sebagai berikut : (1) Apakah dengan proses belajar mengajar mata kuliah akuntansi biaya tentang pengelompokkan biaya dan sistem akauntansi biaya melalui strategi peninjauan kembali "Holly-wood Squares", dapat meningkatkan kemampuan belajar mahasiswa? (2) Apakah strategi peninjauan kembali "Holly-wood Squares" pada mata kuliah akuntansi biaya tentang pengelompokkan biaya dan sistem akauntansi biaya dapat meningkatkan pemahaman dan keaktifan mahasiswa dalam proses belajar mengajar?

Sesuai dengan rumusan masalah, penelitian ini mempunyai tujuan untuk : (1) Menguji efektivitas penerapan strategi peninjauan kembali "Holly-wood Squares" yang disajikan pada proses belajar mengajar mata kuliah akuntansi biaya tentang pengelompokkan biaya dan sistem akauntansi biaya, dalam meningkatkan kemampuan belajar mahasiswa. (2) Membuktikan apakah strategi peninjauan Permainan "Holly-wood Squares" pada mata kuliah akuntansi biaya tentang pengelompokkan biaya dan sistem akauntansi biaya dapat meningkatkan pemahaman dan keaktifan mahasiswa dalam proses belajar mengajar.

Hasil dari pelaksanaan penelitian ini diharapkan dapat memberikan manfaat yang berarti bagi : (1) Bagi mahasiswa, untuk meningkatkan kemampuan belajar, pemahaman dan keaktifan dalam mata kuliah yang bersangkutan; (2) Bagi dosen, penelitian ini bermanfaat untuk mengembangkan rancangan pembelajaran yang dapat meningkatkan kemampuan belajar mahasiswa dalam kegiatan belajar mengajar; (3) Bagi pengembangan institusi, penelitian ini diharapkan menjadi salah satu implementasi Penelitian Pengembangan Pembelajaran sesuai dengan tuntutan sebagai lembaga ilmiah yang dituntut melakukan inovasi pendidikan yang dapat dipertanggungjawabkan secara ilmiah.

\section{Kajian Literatur}

\section{Belajar Kelompok (Cooperative Learning)}

Asnida, 2006 [1] menyatakan bahwa pembelajaran kooperatif (cooperative learning) telah menjadi salah satu pembaharuan dalam pergerakan refomasi pendidikan. Pembelajaran kooperatif sebenarnya merangkum banyak jenis bentuk pengajaran dan pembelajaran. Asasnya ialah menggalakkan mahasiswa belajar bersama-sama dengan berkesan melalui pembentukan komponen yang homogen seperti dalam pendidikan inklutif. Pembelajaran kooperatif atau belajar kelompok boleh digunakan oleh berbagai kelompok umur dan dalam perbagai mata pelajaran. Pembelajaran kooperatif (cooperative learning) dilaksanakan pada kelompok kecil supaya mahasiswa dapat berkerja sama dalam kelompok tersebut untuk mempelajari isi kandungan pelajaran dengan berbagai kemahiran sosial. Sebagai dasarnya, pembelajaran kooperatif melibatkan mahasiswa bekerja sama dalam mencapai satu-satu objektif pembelajaran (Johnson \& Johnson, 1991) [3]. Selain itu, ciri-ciri dari pembelajaran kooperatif antara lain: 


\section{Perjanjian kelompok}

Perjanjian kelompok ialah keberhasilan kelompok dalam mencapai kecemerlangan dalam menguasai sesuatu konsep yang diajarkan. Perjanjian ini dicapai melalui usaha bersama di dalam kelompok. Dalam kelompok ini setiap anggota kelompok mempunyai peranan tertentu dan jelas dalam usaha kelompok mencapai perjanjian yang ditetapkan.

\section{Interaksi sosial ditekankan}

Setiap anggota kelompok akan berinteraksi secara berkesinambungan dalam kelompok. Interaksi yang serentak berlangsung pada saat yang sama untuk setiap kelompok melalui perbincangan yang akan menyebabkan lebih ramai individu yang turut serta mengambil bagian. Setiap anggota kelompok perlu merapatkan diri, saling memenuhi dan bantu membantu.

\section{Mahasiswa perlu saling bergantung positif untuk mencapai objektif gerak kerja}

Keberhasilan kelompok tergantung pada pembelajaran individu anggota suatu kelompok. Setiap anggota mempunyai tanggung jawab terhadap keberhasilan pembelajaran kelompok. Prinsip ini dikenal sebagai saling bergantung secara positif. Untuk mencapai keberhasilan dalam prinsip ini, tugas perlu dialihkan ke semua anggota kelompok untuk menyumbang jawaban atau pendapat. Tanggung jawab individu bermakna, setiap mahasiswa harus melaksanakan tugas masing-masing yang diberikan untuk menyumbangkan pendapatnya pada suatu obyek. Penyertaan ini dimaksudkan supaya semua mahasiswa mempunyai peluang yang sama untuk mengambil bagian dan menyumbang pendapat secara bersama.

Belajar kelompok tidaklah selalu berlangsung efektif, mungkin akan menimbulkan kekhawatiran apabila mahasiswa yang cerdas berada di dalam kelompok yang kurang cerdas, tetapi menurut Slavin (1990), pembelajaran kooperatif akan memberikan manfaat bagi mahasiswa dengan adanya peningkatan kemampuan kognitif mahasiswa. Jika dilakukan dengan sempurna, setiap mahasiswa akan mempunyai tanggung jawab untuk tugasnya masing-masing serta berpeluang mempunyai pengetahuan yang lain melalui kelompok yang berbeda. Untuk tujuan ini, mahasiswa perlu betul-betul memahami sub-topik itu, bukan sekadar menghafal suatu topik. Ini mengakibatkan pemprosesan pada arah yang lebih tinggi, yang meningkatkan daya ingatan dan selanjutnya mereka menunjukkan pencapaian yang lebih baik.

Kajian juga menunjukkan pembelajaran kognitif dapat memperbaiki kemahiran sosial mahasiswa. Anggotaanggota dalam kelompok perlu bekerja sama untuk mencapai objektif pembelajaran. Secara tidak langsung, mereka perlu mempelajari atau memperbaiki kemahiran sosial mereka. Mahasiswa yang bersuara pelan perlu mempertinggi suara supaya didengar dan dipahami oleh anggota kelompok lain. Teguran sesama anggota perlu dilakukan dengan sewajarnya agar kedinamisan kelompok tidak hancur dan gerak kerja berjalan lancar.

Menurut Bennett L. Stevann (1991) [2], pembelajaran kooperatif bagi golongan berbakat telah membawa banyak kesan atau faedah sebagai berikut :

a. Memperbaiki hubungan sosial (konflik antar pribadi berkurang).

b. Meningkatkan pencapaian pemahaman lebih mendalam

c. Meningkatkan kemahiran kepemimpinan, sosial dan teknologi

d. Meningkatkan hasil belajar

e. Meningkatkan keyakinan diri

f. Mengurangi sikap apatis

Beberapa strategi meningkatkan pembelajaran kooperatif yang berkesan:

Pembagian kelompok yang memperbolehkan anggotaanggota dalam kelompok bekerja sama. Faktor yang paling utama di sini ialah jumlah anggota dalam kelompok. Kelompok kecil mempunyai tiga atau empat anggota sudah dianggap paling efektif. Kelompok yang terlalu besar kurang efektif karena pembagian anggota kelompok cenderung menjadi tidak sama rata. Disamping itu, pembentukan kelompok sebaiknya dilakukan oleh guru untuk menggerakkan mahasiswa berkumpul bersama.

a. Tugas harus dibuat terstruktur supaya anggota kelompok saling bergantung untuk mencapai objektif yang ditentukan. Hindarkan pemberian tugas yang boleh diselesaikan tanpa perlu pembagian anggota kelompok. Ini dapat menyebabkan ada anggota kelompok yang 'lepas tangan' ataupun dihindarkan oleh orang lain, dan bagi mahasiswa yang dihindarkan ini, pengalaman pembelajaran sepenuhnya tidak dapat dicapai.

b. Jadikan tanggung jawab pencapaian terletak di kedua tahap individu dan kelompok. Salah satu cara ialah melalui pemberian tugas. Setiap mahasiswa mendapat tugas individu, dan tugas kelompok bergantung kepada tugas individu. Dengan cara itu setiap mahasiswa mempunyai motivasi untuk melakukan yang terbaik untuk diri sendiri dan juga kelompok.

c. Berikan garis panduan tingkah laku dan kemahiran berkomunikasi kepada mahasiswa. Pengajar perlu menjelaskan kepada mahasiswa bagaimana cara berkomunikasi yang baik misalnya bagaimana mengeluarkan pendapat dan bagaimana menghadapi pendapat yang berbeda. Proses ini merupakan proses yang sangat bermanfaat dan perlu ditempuh untuk memperkaya pengalaman belajar dan pembinaan perkembangan mental dan emosional para mahasiswa

d. Pastikan jenis dan kemauan interaksi antara mahasiswa

bertautan. Pengajar harus mengawasi interaksi yang berjalan antar mahasiswa dalam menjalankan aktivitas kelompok di dalam kelas. Perbincangan yang berlaku 
seharusnya berkaitan dengan tugas. Interaksi juga harus berlaku di antara setiap anggota kelompok dan tidak menyisihkan mana-mana anggota kelompok yang lain. Perbincangan dan keputusan juga tidak dimonopoli oleh anggota kelompok tertentu saja.

\section{Strategi Peninjauan Kembali}

Strategi Peninjauan Kembali membahas cara-cara untuk membantu mahasiswa mengingat apa yang telah mereka pelajari dan menguji pengetahuan dan kemampuan mereka yang sekarang. Pengajar akan menjumpai strategi peninjauan kembali yang menarik bagi mahasiswa dan membantu "menyimpan" pembelajaran yang telah mereka terima.

Salah satu strategi peninjauan kembali yang dikembangkan oleh Melvin L. Silberman [9] adalah permainan "Hollywood Squares". Prosedur Strategi Peninjauan Kembali "Holly-wood Squares" yaitu :

Perintahkan tiap mahasiswa untuk menuliskan dua atau tiga pertanyaan yang terkait dengan materi kuliah. Pertanyaan dapat dalam format pilihan ganda, benar/salah atau lisan; Kumpulkan pertanyaan, jika pengajar menghendaki, tambahkan beberapa pertanyaan dari pengajar sendiri; Simulasikan format tayangan permainan tic-tac-toe yang digunakan dalam "Holly-wood Squares". Tatalah tiga kursi di depan kelas. Perintahkan tiga mahasiswa untuk duduk di lantai di depan kursi, tiga duduk di kursi dan tiga lagi berdiri di belakangnya;

Berikan kepada sembilan "selebriti" itu sebuah kartu dengan tanda $\mathrm{X}$ tercetak di satu sisi dan di sisi lain untuk ditempelkan ke tubuh mereka bila pertanyaannya berhasil dijawab;

Perintahkan dua mahasiswa untuk bertugas selaku kontestan. Kontestan memilih anggota dari "Celebrity Square" untuk menjawab pertanyaan permainan;

Ajukan pertanyaan kontestan secara bergiliran. Kontestan menjawab dengan "setuju" atau "tidak setuju" kepada tanggapan panel manakala mereka berusaha membentuk tic-tactoe;

Mahasiswa lain yang tidak terlibat dalam permainan diberi kartu yang menyatakan "setuju" di satu sisi dan "tidak setuju" di sisi lain untuk diberikan kepada kontestan untuk membantu mereka dalam membantu keputusan;

Lakukan rotasi pada para "selebriti" itu. Pasangkan mahasiswa. Perintahkan mereka untuk bermain tictac-toe kepada satu sama lain, berdasarkan kemampuan mereka untuk menjawab pertanyaan.

\section{Ruang Lingkup Materi Mata Kuliah Akuntansi Biaya tentang Dasar Pengelompokkan Biaya dan Sistem Akuntansi Biaya.}

Dasar pengelompokkan biaya adalah proses terhadap biayabiaya yang ada dalam perusahaan diklasifikasikan sesuai dengan kepentingan manajemen (Matz, Usry \& Hammer. 1997) [6]. Dasar pengelompokkan biaya berdasarkan klasifikasi biaya adalah: klasifikasi biaya atas dasar fungsi biaya, klasifikasi biaya atas dasar hubungan dengan sesuatu yang dibiayai, klasifikasi biaya atas dasar perubahan volume produksi, klasifikasi biaya atas dasar periode akuntansi pembebanan biaya. SistemAkuntasi Biaya (Rayburn. L. Gayle 1999) [8] adalah keseluruhan dari prosedur-prosedur yang terinteraksi dan meliputi buktibukti, catatan-catatan, serta informasi yang bertujuan untuk melaksanakan kegiatan perusahaan serta membantu manajemen dalam menyediakan informasi biaya yang diperlukan. Sitem Akuntansi Biaya yang diajarkan adalah :

a. Sistem harga pokok yang ditentukan dibelakang (post determine cost system) berupa sistem harga pokok pesanan dan sistem harga pokok proses;

b. dan sistem harga pokok yang ditentukan dimuka (pre determine cost system) berupa sistem harga pokok taksiran dan sistem harga pokok standar;

\section{Metode Penelitian}

\section{Rancangan Penelitian}

Penelitian ini dilaksanakan dalam dua siklus, yang masingmasing siklus meliputi tahap refleksi awal, perencanaan (planning), pelaksanaan tindakan (acting), observasi dan refleksi akhir. Refleksi awal berupa kajian dan renungan terhadap pengalaman mengajar mata kuliah Akuntansi Biaya di Jurusan Akuntansi Politeknik Negeri Samarinda yang selama ini dilaksanakan. Adapun langkah-langkah penelitian yang ditempuh setiap siklus secara lebih rinci dapat dijelaskan sebagai berikut:

\section{Perencanaan (planning)}

Tahap perencanaan ini adalah sebagai berikut: (a) membuat skenario pembelajaran, (b) membuat lembar observasi untuk melihat suasana pembelajaran, dan aktivitas mahasiswa, (c) membuat dan menyediakan media pembelajarannya, dan (d) mendesain alat evaluasi untuk melihat apakah mahasiswa dengan menggunakan Strategi Peninjauan Kembali ala Permainan "Holly-wood Squares", dapat meningkatkan hasil belajar.

\section{Pelaksanaan Tindakan (acting)}

Pelaksanaan tindakan merupakan suatu kegiatan dilaksanakannya skenario pembelajaran yang telah direncanakan. Prosedur Strategi Peninjauan Kembali dalam "Hollywood Squares" yaitu:

a. Perintahkan tiap mahasiswa untuk menuliskan dua atau tiga pertanyaan yang terkait dengan materi kuliah. Pertanyaan dapat dalam format pilihan ganda, benar/salah atau lisan.

b. Kumpulkan pertanyaan, jika pengajar menghendaki, tambahkan beberapa pertanyaan dari pengajar sendiri.

c. Simulasikan format tayangan permainan tic-tac-toe yang digunakan dalam "Holly-wood Squares". Tatalah tiga kursi di depan kelas. Perintahkan tiga mahasiswa untuk duduk di lantai di depan kursi, tiga duduk di kursi dan tiga lagi berdiri di belakangnya.

d. Berikan kepada sembilan "selebriti" itu sebuah kartu dengan tanda $\mathrm{X}$ tercetak di satu sisi dan di sisi lain 
untuk ditempelkan ke tubuh mereka bila pertanyaannya berhasil dijawab.

e. Perintahkan dua mahasiswa untuk bertugas selaku kontestan. Kontestan memilih anggota dari "Celebrity Square" untuk menjawab pertanyaan permainan.

f. Ajukan pertanyaan kontestan secara bergiliran. Kontestan menjawab dengan "setuju" atau "tidak setuju" kepada tanggapan panel manakala mereka berusaha membentuk tictac-toe.

g. Mahasiswa lain yang tidak terlibat dalam permainan diberi kartu yang menyatakan "setuju" di satu sisi dan "tidak setuju" di sisi lain untuk diberikan kepada kontestan untuk membantu mereka dalam membantu keputusan.

h. Lakukan rotasi pada para "selebriti" itu.

i. Pasangkan mahasiswa. Perintahkan mereka untuk bermain tic-tac-toe kepada satu sama lain, berdasarkan kemampuan mereka untuk menjawab pertanyaan.

\section{Pengamatan (observing)}

Pengamatan adalah suatu kegiatan mengamati jalannya pelaksanaan tindakan untuk memantau sejauh mana efek tindakan pembelajaran dengan menggunakan Strategi Peninjauan Kembali dalam "Holly-wood Squares" telah mencapai tujuan. Pengumpulan data melalui instrumen yang telah dibuat dilakukan pada tahap ini, keaktifan mahasiswa dalam proses pembelajaran dan data kualitatif yaitu suasana kelas, tanggapan mahasiswa dan dosen. Data ini diambil melalui penggunaan alat instrumen yaitu lembar observasi, dan jurnal pengajar (monitoring pengajaran) sebagai catatan di lapangan. Data-data yang diambil dengan cara ini diharapkan meningkatkan validitas data yang diperoleh.

\section{Refleksi (reflecting)}

Refleksi merupakan suatu kegiatan mengulas secara kritis perubahan yang terjadi pada mahasiswa, suasana di kelas dan pengajar. Data observasi yang telah diperoleh ini akan dianalisis dan direfleksikan bersama untuk mengetahui perubahan yang telah terjadi selama tindakan pembelajaran dengan menerapkan Strategi Peninjauan Kembali dalam "Holly-wood Squares" itu dilaksanakan. Hasil analisis dan refleksi ini digunakan untuk perbaikan pelaksanaan perkuliahan pada siklus berikutnya.

\section{Lokasi Penelitian}

Penelitian ini dilaksanakan pada mahasiswa Semester 3 Program Studi Akuntansi Jenjang D3, dan Program Studi Akuntansi Manajerial Jenjang D4 di Jurusan Akuntansi Politeknik Negeri Samarinda yang penulis ajar dalam mata kuliah Akuntansi Biaya. Mata kuliah ini merupakan kelompok mata kuliah Keahlian Berkarya dengan bobot 3 SKS atau dengan jumlah tatap muka 6 x 45 menit dalam 1 minggu. Penelitian ini akan dilakukan pada semester gasal tahun ajaran 2016/2017. Dalam pelaksanaannya, penelitian ini melibatkan 1 orang dosen yang merupakan pengajar mata kuliah Akuntansi Biaya.

\section{Metode Pengumpulan Data}

Metode pengumpulan data yang dilakukan dalam penelitian ini adalah sebagai berikut :

\section{Dokumentasi}

Dokumentasi adalah metode pengumpulan data dengan menggunakan dokumen-dokumen sebagai bahan acuan untuk kepentingan penelitian. Dalam penelitian ini yang digunakan adalah daftar nilai mata kuliah Akuntansi Biaya dan dokumentasi kegiatan pada masing-masing siklus.

\section{Metode tes}

Tes adalah serentetan pertanyaan atau alat lain yang digunakan untuk mengukur ketrampilan, pengetahuan, intelejensi, kemampuan dan bakat yang dimiliki individu atau kelompok. Tes yang digunakan dalam penelitian ini adalah tes prestasi yaitu tes yang digunakan untuk mengukur kemampuan mahasiswa setelah mengerjakan sesuatu. Tes disini berupa pre test dan post test.

\section{Metode Observasi}

Observasi adalah pengamatan yang dilakukan pada subyek penelitian. Aspek yang diamati dalam penelitian ini adalah perhatian mahasiswa dalam menerima pembelajaran, bahasa yang digunakan dosen dalam pembelajaran, motivasi dalam menerima pelajaran, kerjasama dan partisipasi mahasiswa dalam proses pembelajaran.

\section{Jurnal}

Jurnal mahasiswa dan pengajar diisi pada akhir pembelajaran. Jurnal mahasiswa berisi tentang kesulitan mahasiswa dalam pembelajaran, pendapat atau komentar mahasiswa pada Strategi Peninjauan Kembali "Holly-wood Squares" yang dilakukan oleh pengajar dan pesan, kesan ataupun saran tentang pembelajaran tersebut.

\section{Analisis Data}

Analisis data yang digunakan adalah analisis deskriptif prosentase. Analisis data ini digunakan untuk menganalisis mengenai prosentase hasil dari pre test dan post test yang dilakukan oleh dosen pada saat pelaksanaan tindakan. Sedangkan untuk mengetahui sejauhmana Strategi Peninjauan Kembali "Holly-wood Squares"dapat meningkatkan kemampuan belajar mahasiswa dilihat dari hasil belajar mahasiswa yaitu dengan cara total skor dari satu kelas dibagi dengan jumlah mahasiswa sehingga dapat diketahui skor rata- rata hasil belajar di kelas tersebut, skor rata-rata tersebut dibandingkan antar siklus. Pada penelitian tindakan kelas ini, peneliti menetapkan target pencapaian nilai mahasiswa dengan batas minimal 70 atau B. 
Mahasiswa dikatakan berhasil mencapai target jika telah mencapai nilai minimal.

\section{Hasil dan Pembahasan}

\section{Karakteristik Subyek Penelitian}

Penelitian ini dilaksanakan pada mahasiswa Semester 3 Program Studi Akuntansi Jenjang D3 di Jurusan Akuntansi dan mahasiswa Semester 3 Program Studi S1 Terapan Akuntansi Manajerial pada Politeknik Negeri Samarinda yang mengikuti mata kuliah Akuntansi Biaya. Mata kuliah ini merupakan kelompok mata kuliah Keahlian Berkarya dengan bobot 3 SKS atau dengan jumlah tatap muka 6 x 45 menit dalam 1 minggu. Penelitian ini dilakukan pada semester gasal tahun ajaran 2016/2017. Dalam pelaksanaannya penelitian ini melibatkan 1 orang dosen yang merupakan tim pengajar mata kuliah Akuntansi Biaya. Jumlah responden yang berpartisipasi dalam penelitian ini sebanyak 44 mahasiswa. Berdasarkan jenis kelamin, diketahui 8 subjek atau 18,2\% adalah subjek lakilaki dan 36 subjek atau $81,8 \%$ adalah subjek wanita. Data di atas dapat dilihat pada Tabel 1 di bawah ini.

Tabel 1.

Karakteristik Subjek Penelitian

\begin{tabular}{|c|c|c|c|}
\hline \multicolumn{2}{|c|}{ Responden N=44 } & \multicolumn{2}{c|}{ Persentase Total } \\
\hline Laki-laki & Perempuan & $\begin{array}{c}\text { Laki- } \\
\text { laki }\end{array}$ & Perempuan \\
\hline 8 & 36 & $18,2 \%$ & $81,8 \%$ \\
\hline
\end{tabular}

Penelitian tindakan kelas dengan mengimplementasikan strategi peninjauan kembali model permainan "holly-wood squares" dapat meningkatkan pemahaman mahasiswa terhadap prosedur pengelompokkan biaya. Berikut data hasil analisis prestasi belajar mahasiswa Mata Kuliah Akuntansi Biaya.

Tabel 2.

Data Hasil Analisis tentang prestasi belajar mahasiswa Mata Kuliah Akuntansi Biaya

\begin{tabular}{|l|c|c|c|c|}
\hline $\begin{array}{c}\text { Keterangan } \\
\text { Nilai }\end{array}$ & $\begin{array}{c}\text { Pre } \\
\text { Test }\end{array}$ & Siklus 1 & Siklus 2 & $\begin{array}{c}\text { Post } \\
\text { Test }\end{array}$ \\
\hline Nilai Terendah & 27 & 50 & 60 & 40 \\
\hline Nilai Tertinggi & 38 & 75 & 87 & 90 \\
\hline Rata-rata Kelas & 30,32 & 68 & 72 & 78 \\
\hline $\begin{array}{l}\text { Pencapaian } \\
\text { Target nilai }\end{array}$ & $0 \%$ & $45,43 \%$ & $58,75 \%$ & $75,53 \%$ \\
\hline
\end{tabular}

Berdasarkan batas minimal nilai yang harus dicapai oleh mahasiswa yaitu mahasiswa dikatakan berhasil mencapai target nilai yang ditetapkan oleh dosen apabila memperoleh nilai minimal 71 (B) maka keadaan awal (sebelum diberi tindakan) dan keadaan akhir setelah diberi tindakan adalah sebagai berikut : pada keadaan awal belum ada yang mencapai nilai 71, sedangkan pada siklus pertama yang memperoleh nilai 71 atau di atas 71 sebanyak $45,43 \%$, pada siklus kedua sebanyak 58,75\%. Pada uji akhir yang mencapai nilai 71 sebanyak $75,53 \%$.

\section{Hasil Observasi Pra Siklus}

Sebelum penelitian ini dilakukan, peneliti : (a) membuat skenario pembelajaran, (b) membuat lembar observasi untuk melihat suasana pembelajaran, dan aktivitas mahasiswa, (c) membuat dan menyediakan media pembelajarannya, dan (d) mendesain alat evaluasi untuk melihat apakah mahasiswa dengan menggunakan Strategi Peninjauan Kembali ala Permainan "Holly-wood Squares", dapat meningkatkan hasil belajar. Pada pertemuan I, peneliti menyampaikan model pembelajaran dengan menggunakan Strategi Peninjauan Kembali ala Permainan "Holly-wood Squares" untuk kuliah Akuntansi Biaya dan tujuan dari penelitian ini dilakukan. Sebelum siklus I dilakukan, yaitu pada pertemuan kedua, peneliti memberikan pre tes kepada seluruh mahasiswa mengenai materi siklus I dan siklus II yaitu tentang prosedur pengelompokkan biaya.

\section{Siklus I}

Pada siklus I, tiap mahasiswa diperintahkan untuk menulis dua atau tiga pertanyaan yang terkait dengan materi kuliah. Pertanyaan dapat dalam format pilihan ganda, benar/salah atau lisan. Materi pada siklus I adalah tentang prosedur pengelompokkan biaya yaitu instruksi rinci untuk mengumpulkan jenis-jenis biaya yang harus dikelompokkan berdasarkan fungsi dari tiap departemen. Setelah pertanyaan dikumpulkan, peneliti mensimulasikan format tayangan permainan tic-tac-toe yang digunakan dalam "Holly-wood Squares" dengan menata tiga kursi di depan kelas kemudian memerintahkan tiga mahasiswa untuk duduk di lantai di depan kursi, tiga duduk di kursi dan tiga lagi berdiri di belakangnya. Setelah itu memberikan kepada sembilan "selebriti" itu sebuah kartu dengan tanda $\mathrm{X}$ tercetak di satu sisi dan di sisi lain untuk ditempelkan ke tubuh mereka bila pertanyaannya berhasil dijawab. Peneliti memerintahkan dua mahasiswa untuk bertugas selaku kontestan. Kontestan memilih anggota dari "Celebrity Square" untuk menjawab pertanyaan permainan.

Kemudian ajukan pertanyaan kontestan secara bergiliran. Kontestan menjawab dengan "setuju" atau "tidak setuju" kepada tanggapan panel manakala mereka berusaha membentuk tic-tac-toe. Mahasiswa lain yang tidak terlibat dalam permainan diberi kartu yang menyatakan "setuju" di satu sisi dan "tidak setuju" di sisi lain untuk diberikan kepada kontestan untuk membantu mereka dalam membuat keputusan. Rotasi dilakukan pada para "selebriti" itu dengan cara memasangkan mahasiswa. Terakhir mereka diminta untuk bermain tic-tac-toe satu sama lain, berdasarkan kemampuan mereka untuk menjawab pertanyaan.

Refleksi pada siklus I ini, masih banyak mahasiswa yang membuat pertanyaan-pertanyaan yang bersifat mudah, 
sehingga dengan cepat kelompok yang bertugas menjawab pertanyaan. Soal atau pertanyaan yang dibuat kurang variasi, sehingga tidak ada tantangan dari anggota celebrity square untuk menjawab pertanyaan. Kemudian mahasiswa yang tidak terpilih untuk menjadi kontestan atau selebriti kurang aktif menanggapi atau merespon permainan ini, hal ini disebabkan banyak dari mereka masih belum paham terhadap permainan ini.

\section{Siklus II}

Berdasarkan hasil refleksi dari Siklus I, maka peneliti mengatur kembali permainan ini agar supaya semua mahasiswa yang terlibat baik sebagai kontestan, selebriti maupun mahasiswa yang tidak terpilih sebagai kontestan ataupun selebriti, ikut aktif dalam strategi pembelajaran ini. Peneliti mengungkapkan kembali tujuan dari penelitian ini kemudian menjelaskan secara detail langkah-langkah permainan ini dan tugas setiap pemain

Kemudian setiap pertanyaan yang diajukan harus direspon oleh mahasiswa yang tidak terlibat sebagai kontestan atau selebriti. Pertanyaan yang dibuat dalam siklus II ini adalah tentang pengelompokkan biaya, peneliti meminta semua mahasiswa untuk membuat pertanyaan yang bagus dan bermutu sehingga selebriti yang menjawab pertanyaan tersebut dapat berfikir atau menganalisis jawaban. Pertanyaan yang dibuat dipastikan tidak sama antara satu mahasiswa dengan mahasiswa yang lain. Pertanyaan bisa bersumber dari buku atau literature selain literature wajib.

Hasil refleksi dari siklus II ini adalah semua mahasiswa sudah ikut berpartisipasi aktif dalam strategi pembelajaran ini. Pengelolaan pembelajaran oleh dosen dengan mengimplementasikan Strategi Peninjauan Kembali ala Permainan "Holly-wood Squares" selama kegiatan pembelajaran berlangsung yang diamati dengan pedoman observasi, hasilnya dapat dilihat pada Tabel 3. di bawah ini

Tabel 3.

Data Hasil Observasi mengenai Ketrampilan Dosen dalam Pengelolaan Pembelajaran dengan menggunakan Strategi Peninjauan Kembali ala Permainan "Holly-wood Squares"

\begin{tabular}{|c|c|c|c|c|}
\hline \multirow{2}{*}{ No } & \multirow{2}{*}{$\begin{array}{c}\text { Variabel yang } \\
\text { diamati }\end{array}$} & \multicolumn{2}{|c|}{ Skor Observer } & \multirow{2}{*}{$\begin{array}{l}\text { Rata- } \\
\text { rata }\end{array}$} \\
\hline & & Siklus 1 & Siklus 2 & \\
\hline \multirow[t]{2}{*}{1.} & Penggunaan & 3 & 3,5 & 3,25 \\
\hline & $\begin{array}{l}\text { Bahasa oleh } \\
\text { Dosen }\end{array}$ & & & \\
\hline 2. & $\begin{array}{l}\text { Suasana } \\
\text { Belajar }\end{array}$ & 3 & 4 & 3,5 \\
\hline 3. & $\begin{array}{l}\text { Ketepatan } \\
\text { Penggunaan } \\
\text { Metode }\end{array}$ & 3,5 & 4 & 3,75 \\
\hline 4. & $\begin{array}{l}\text { Penghargaan } \\
\text { terhadap } \\
\text { mahasiswa }\end{array}$ & 3,5 & 3,5 & 3,5 \\
\hline 5. & $\begin{array}{l}\text { Ketepatan } \\
\text { Evaluasi }\end{array}$ & 3 & 4 & 3,5 \\
\hline
\end{tabular}

Dari Tabel 3 di atas menunjukkan ketrampilan Dosen dalam pengelolaan pembelajaran dengan rentangan penilaian $1-4$ pada kategori baik (rata-rata dari semua aspek yang diamati 3,5). Tabel di atas juga menunjukkan adanya peningkatan ketrampilan dosen dalam pengelolaan pembelajaran yang semakin baik pada siklus berikutnya. Sedangkan mengenai minat, keaktifan dan kerjasama mahasiswa dalam proses pembelajaran Mata Kuliah Akuntansi Biaya, dapat dilihat Tabel 4. berikut ini:

Tabel 4.

Data Hasil Observasi mengenai Minat, Keaktifan, dan Kerjasama Mahasiswa

\begin{tabular}{|l|l|c|c|c|}
\hline No & $\begin{array}{l}\text { Variabel yang } \\
\text { diamati }\end{array}$ & \multicolumn{2}{|c|}{ Skor Observer } & Rata- \\
\cline { 3 - 5 } 1. & Siklus 1 & Siklus 2 & Minat \\
Mahasiswa & 3 & 3,5 & 3,25 \\
\hline 2. & $\begin{array}{l}\text { Keaktifan } \\
\text { Mahasiswa }\end{array}$ & 3,5 & 4 & 3,75 \\
\hline \multirow{2}{*}{3.} & $\begin{array}{l}\text { Kerjasama } \\
\text { Mahasiswa } \\
\text { dalam proses } \\
\text { pembelajaran }\end{array}$ & 3,5 & 4 & 3,75 \\
\hline \multicolumn{3}{|c|}{ Rata-Rata } & & $\mathbf{3 , 5 8}$ \\
\hline
\end{tabular}

Dari Tabel 4 di atas menunjukkan secara keseluruhan dari aspek yang diamati mengenai mahasiswa dapat dikategorikan baik dengan rata-rata 3,58. Tabel tersebut juga menunjukkan adanya peningkatan minat, keaktifan dan kerjasama mahasiswa pada siklus berikutnya.

\section{Pembahasan}

Strategi Peninjauan Kembali ala Permainan "Holly-wood Squares" ini sangat sesuai sekali diterapkan dalam pembelajaran Akuntansi Biaya. Pada setiap siklus, mahasiswa tampak lebih bersemangat dan mempunyai minat untuk mempelajari suatu pokok bahasan baru. Aktivitas yang dilakukan dosen pada setiap putaran dengan perencanaan pembelajaran yang telah disusun mengurangi dominasi dosen dalam proses pembelajaran. Hal ini karena mahasiswa terlibat aktif melakukan diskusi dan mengerjakan soal-soal latihan. Dosen hanya berfungsi sebagai fasilitator dalam proses perkuliahan.

Adanya kegiatan permainan dalam proses pembelajaran ini memberi banyak keuntungan. Mahasiswa secara individual dapat mengembangkan pemikiran dan daya kreatif dalam pembuatan soal, menganalisis jawaban secara cepat dan tepat dan siap dalam menerima pokok bahasan baru. Dan secara kelompok dapat memperbaiki hubungan sosial (mengurangi konflik pribadi). Keuntungan lainnya adalah pemahaman mahasiswa akan materi suatu pokok bahasan akan lebih mendalam. 


\section{Simpulan dan Saran}

\section{Simpulan}

Hasil penelitian menunjukkan prestasi belajar mahasiswa mengalami peningkatan di setiap siklusnya. Hasil tes mahasiswa sebelum Strategi Peninjauan Kembali model Permainan "Holly-wood Squares" diterapkan yang memperoleh nilai minimal 71 sebanyak $0 \%$, setelah penerapan strategi ini yang memperoleh nilai minimal 71 sebanyak $75,53 \%$. Hasil pengamatan mengenai ketrampilan dosen dalam pengelolaan pembelajaran dengan Strategi Peninjauan Kembali ala Permainan "Holly-wood Squares" dengan rentangan $1-4$ menunjukkan hasil baik dengan rerata siklus 1 dan siklus 2 sebesar 3,5. Sedangkan minat, keaktifan dan kerjasama mahasiswa dalam proses pembelajarandengan rentangan $1-4$ hasilnya baik $(3,58)$. Skor tersebut merupakan rerata dari seluruh aspek yang diamati pada dua siklus.

\section{Acknowledgment}

Ucapan terima kasih kepada Lewi Patabang atas partisipasinya membantu dalam penelitian dan seluruh mahasiswa semester III Jurusan Akuntansi Politeknik Negeri Samarinda yang bersedia menjadi responden dalam penelitian.

\section{Saran}

Berdasarkan hasil penelitian yang diperoleh maka diberikan saran atau rekomendasi sebagai berikut : kepada dosen pengampu Mata Kuliah Akuntansi Biaya disarankan untuk menerapkan Strategi Peninjauan Kembali ala Permainan "Holly- wood Squares" dalam pembelajaran Biaya. Metode ini terbukti dapat meningkatkan kemampuan mahasiswa dalam memahami konsep dasar Biaya.

Mahasiswa secara individual dapat mengembangkan pemikiran dan daya kreatif dalam pembuatan soal, menganalisis jawaban secara cepat dan tepat dan siap dalam menerima pokok bahasan baru. Selain itu juga hasil penelitian ini dapat ditindaklanjuti dengan penelitian lanjutan pada mata kuliah lain

\section{Daftar Rujukan}

[1] Asnida, Selma, Zarinah, S; Katrie \& W.S Chiong. (2006). Pembelajaran Kooperatif Yang Berkesan. Tersedia pada http: //www.geocities.com/gerdner028/ilmiahl.htm. Diakses pada tanggal 20 Juni 2007.

[2] B.Bennett, C. Rolheiser-Bennett, L.Stevann (1991). Cooperative Learing Where Heart Meets Mind. Tersedia pada http:// www.geocities.com/ Cooperative Learing/ilmiahl.htm. Diakses pada tanggal 29 Juni 2007.
[3] Johnson, \& Johnson, R.T (1991). Learrning together and alone : Cooperative, Competitive, and individualistic learning (3rd Ed.). Upper Saddle river, NJ: Prentice-Hall.

[4] Keputusan Menteri Tenaga Kerja Dan Transmigrasi Repulik Indonesia Nomor 182 Tahun 2013.

[5] LP3-ITB. 2003. Ketrampilan Belajar. Tersedia pada http:// www.itb.co.id/lp3/ketrampilan belajar.htm.

[6] Matz, Usry \& Hammer. (1997). Akuntansi Biaya: Perencanaan dan Pengendalian Edisi 9. Penerbit Erlangga.

[7] Peraturan Presiden Nomor 08 tahun 2012, tentang Kerangka Kualifikasi Nasional Indonesia (KKNI),

[8] Rayburn. L. Gayle (1999). Akuntansi Biaya: Menggunakan Pendekatan Manajemen Biaya. Edisi 6. Penerbit Erlangga.

[9] Silberman, Melvin. 2006. Active Learning. Penerbit Nusa Media. Bandung. Slavin, R. (1990) Cooperative Learning : Theory, Research Practice. Englewood Cliff, NJ: Prentice Hall.

[10] Undang-Undang Nomor 13 Tahun 2003 tentang Ketenagakerjaan 